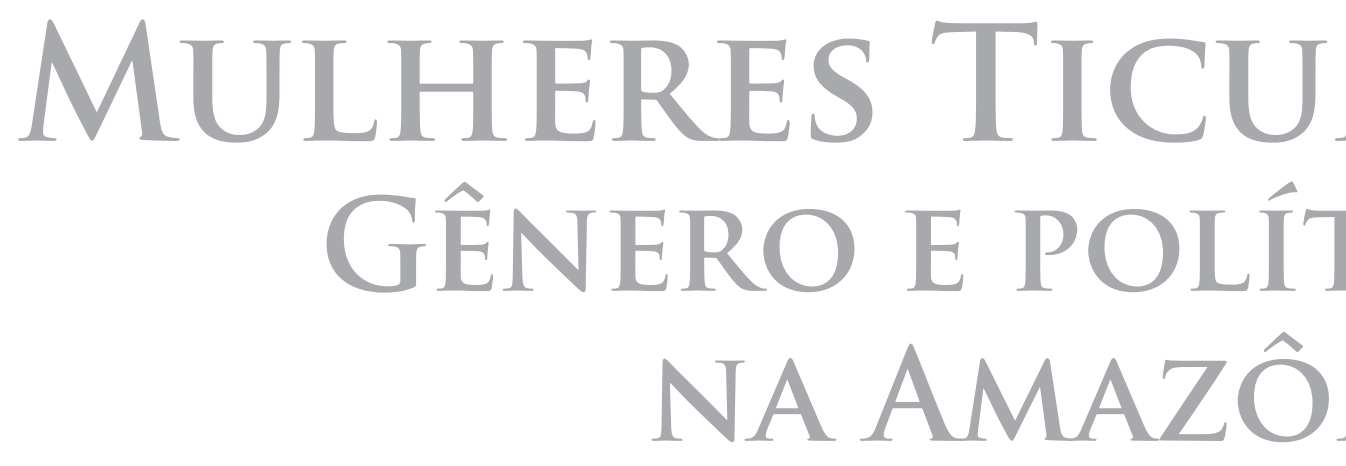




\section{MULHERES TICUNA: GÊNERO E POLÍTICA NA AMAZÔNIA.}

\section{E LIZABETH DEL SOCORRO RUANO I BARRA}

LABORATÓRIO DE ESTUdOS E PESQUISAS EM MOVIMENTOS INDÍGENAS, POLÍTICAS INDIGENISTAS E INDIGENISMO (LAEPI - CEPPAC/ICS/UNB).

\section{LILIANA VIGNOLI DE SALVO SOUZA}

LABORATÓRIO DE ESTUDOS E PESQUISAS EM MOVIMENTOS INDÍGENAS, POLÍTICAS INDIGENISTAS E INDIGENISMO (LAEPI - CEPPAC/ICS/UNB). 


\title{
MULHERES TICUNA: GÊNERO E POLÍTICA NA AMAZÔNIA.
}

\section{Resumo}

Este trabalho analisa a inserção das mulheres indígenas no campo político interétnico a partir das narrativas de lideranças femininas e masculinas do povo Ticuna na fronteira colombo-brasileira. Os dados empíricos foram coletados mediante pesquisa etnográfica e sua análise inspira-se no debate acadêmico sobre gênero e feminismos étnicos em perspectiva comparada. A incursão das mulheres indígenas na política interétnica contribui para a crescente politização do seu lugar no mundo, a qual se desdobra em múltiplas exigências públicas e domésticas.

Palavras chave: feminismos étnicos, liderança, comparação, fronteira Brasil-Colômbia.

\section{TICUNA WOMEN: GENDER AND POLITICS IN AMAZONIA.}

\begin{abstract}
This paper analyzes the insertion of indigenous women in the interethnic political field from the narratives of women and men leaders of the Ticuna people in the colombian-brazilian border. The empirical data was collected through ethnographic research and its analysis is inspired by the academic debate on gender and ethnic feminisms in comparative perspective. The incursion of indigenous women into interethnic politics contributes to the growing politicization of their place in the world, which is deployed in multiple public and domestic demands.
\end{abstract}

Key words: ethnic feminisms, leadership, comparison, Brazil-Colombia border. 


\section{MUJERES TICUNA: GÉNERO Y POLÍTICA EN EL AMAZONAS}

\section{Resumen}

Este trabajo analiza la inserción de las mujeres indígenas en el campo político interétnico a partir de las narrativas de liderazgos femeninos y masculinos del pueblo Ticuna en la frontera colombo-brasilera. Los datos empíricos fueron recolectados mediante investigación etnográfica y su análisis se inspira en el debate académico sobre género y feminismos étnicos en perspectiva comparada. La incursión de las mujeres indígenas en la política interétnica contribuye a la creciente politización de su lugar en el mundo, que se traduce en múltiples exigencias públicas y domésticas.

Palabras clave: feminismos étnicos, liderazgo, comparación, frontera Brasil-Colombia

Endereço do $1^{\circ}$ autor para correspondência: SQN 203 Bloco C Apartamento 611. Brasília. CEP: 70833030. 


\section{INTRODUÇÃO}

Este trabalho aponta a crescente importância das mulheres indígenas no campo da política interétnica, delimitando a análise ao povo Ticuna, na região da fronteira colombo-brasileira. A partir das trajetórias pessoais de indígenas Ticuna se dimensionam os constrangimentos e desdobramentos da in- cursão feminina na esfera pública, com base nas suas experiências como autoridades políticas indígenas no contexto amazônico. Para tanto, retomam-se os achados da pesquisa realizada por Souza (2015), a qual abordou as trajetórias de lideranças políticas Ticuna nas cidades de Tabatinga (Amazonas/Brasil) e Letícia (Amazonas/Colômbia).

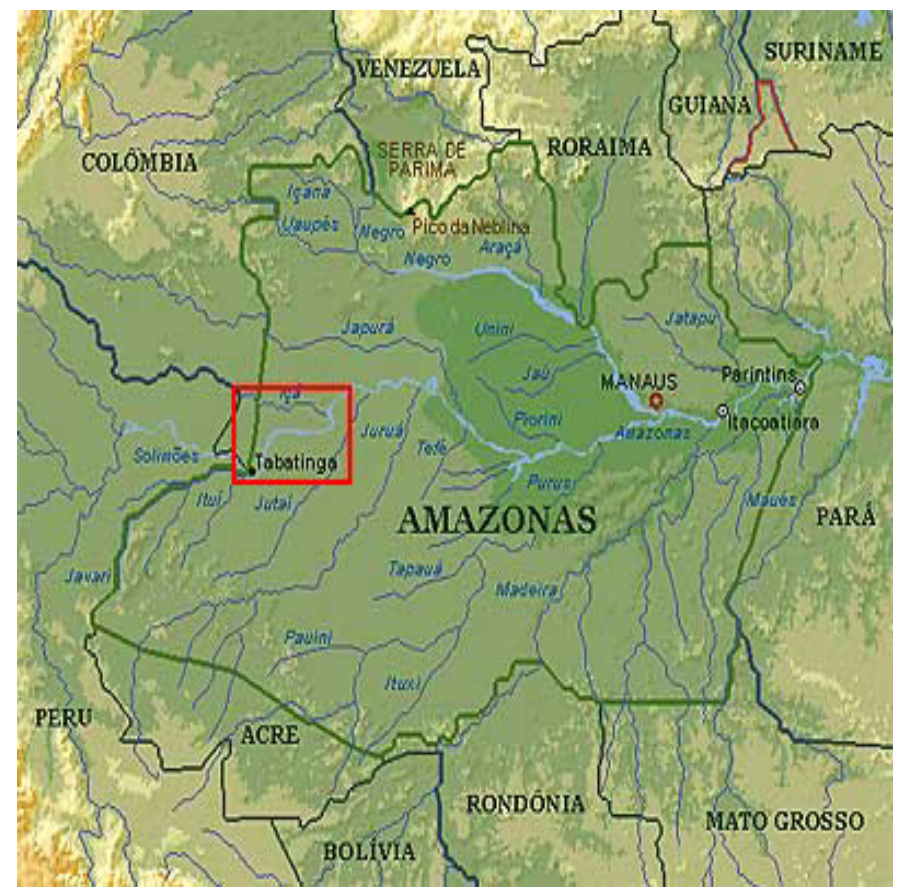

Região pesquisada (fonte: http://www.studium.iar.unicamp.br/seis/diario/)

Metodologicamente é importante frisar que as narrativas que constituem o ponto central desta análise foram obtidas em perspectiva etnográfica. $\mathrm{O}$ trabalho de campo realizado entre setembro, outubro e novembro de 2014 , em Leticia e Tabatinga, fundamentou-se em encontros para ouvir histórias e conversar com lideranças indígenas Ticuna, Cocama, Yagua, Miranha e Uitoto, e com não-indígenas acerca do campo político interétnico e da formação das lideranças indígenas. A análise proposta neste artigo prioriza as narrativas de Ruth Lorenzo, Alis Puricha Peña e Mislene Mendes ${ }^{1}$, três mulheres Ticuna com reconhecida trajetória política no campo interétnico na fronteira colombo-brasileira.

A escolha metodológica de pesquisar em área de fronteira se justifica segundo Silva e Baines (2009), para os quais 
as situações socioculturais encontradas nessas áreas são capazes de revelar as dinâmicas interculturais de toda uma região. Ao envolver um mesmo povo indígena em uma fronteira internacional sul-americana, as reflexões sobre cada lugar servem também como contraponto para pensar a intersecção entre etnicidade e nacionalidade, tal como apontou Cardoso de Oliveira (2000:14) ${ }^{2}$, que considerava o contexto das fronteiras entre países "um dos mais desafiantes cenários de investigação sobre a relação dialética entre identidade étnica e identidade nacional", face ao caráter dinâmico das relações sociais vividas ali. Em seus estudos envolvendo grupos étnicos situados em áreas de fronteira entre Estados nacionais, Cardoso de Oliveira percebeu a nacionalidade como uma segunda identidade e reconheceu que essa categoria é instrumentalizada em conformidade com situações concretas nas quais os indivíduos e grupos étnicos se veem inseridos (idem, 2000:17).

A análise apresentada adotou a perspectiva comparativa. Frederick Barth (2000) defendeu a comparação analítica de casos específicos, com atenção especial para os dados empíricos. Nessa trilha, a comparação é eficaz para evidenciar semelhanças e diferenças nos processos históricos dos Ticuna em diferentes contextos nacionais. A interpretação das narrativas inspirou-se na perspectiva da análise de discurso crítico (Rezende \& Ramalho, 2009) em diálogo com o debate sobre feminismos e gênero (Pancho, 2007; Cabnal, 2010; Miñoso, Correal, Muñoz, 2014; Dutra \& Bandeira, 2015).
Atualmente as mulheres indígenas em geral, e as Ticuna em particular, experimentam processos de crescente politização do seu lugar no âmbito público. Essas transformações sociopolíticas estimulam a sua inserção em espaços até então nomeadamente masculinos, por isso essas dinâmicas não ocorrem isentas de tensões. Pois, até a década de 1970, estudos de Oliveira Filho (1977; 1988) sobre a organização social Ticuna no Alto Solimões constataram que as mulheres, assim como os jovens, não eram consideradas atores políticos. $\mathrm{Ou}$ seja, às mulheres correspondiam tarefas do âmbito doméstico, sendo tal demarcação pautada na lógica da divisão sexual do trabalho, que determina que à mulher corresponde a reprodução, portanto, todas as atividades atreladas ao âmbito doméstico.

Sacchi (2003) demarcou como fato relativamente recente no Brasil tanto a inserção de mulheres indígenas no âmbito público, quanto o surgimento de organizações indígenas femininas. Em 2002, foi realizado o $1^{\circ}$ Encontro das Mulheres Indígenas da Amazônia Brasileira em Manaus, com participação de 70 lideranças de 20 organizações e 30 povos indígenas. $\mathrm{O}$ evento objetivou promover a participação das mulheres indígenas, assegurar seus direitos e contribuir para o avanço do movimento indígena. Nesse ano, também foram criados os Departamentos de Mulheres Indígenas na Coordenação das Organizações Indígenas da Amazônia Brasileira (COIAB) e na Federação das Organizações Indígenas do Rio Negro (FOIRN).

A década de 1990 evidenciou o surgimento de processos organizativos das 
mulheres indígenas conjugados com as demandas coletivas dos seus povos de origem, que visibilizaram demandas específicas de gênero (Castillo, 2008, Bórquez et al, 2011). Contudo, Lavrin (1985) afirma que essas dinâmicas já se encontravam em curso no continente latino-americano em décadas anteriores, embora estivessem invisibilizadas. $\mathrm{Na}$ Colômbia, no momento presente, as mulheres indígenas buscam posicionar a dimensão de gênero no contexto local, nacional e global mediante reivindicações coletivas e individuais em torno do seu lugar no mercado do trabalho e nas decisões relacionadas com seus corpos (Ulloa, 2007).

Para Pancho (2007), essa dinâmica feminina indígena na Colômbia se ampara nas concepções de complementariedade com os homens porque ambos compartilham cotidianamente visões de mundo. Essas relações de reciprocidade entre homens e mulheres indígenas foram estabelecidas historicamente, contudo, abre-se um logo percurso para a real compreensão dessa dinâmica. Botero (2016) analisou o Programa de mulheres chamado Tejido de las $M u$ jeres da Asociación de Cabildos Indígenas del Norte de Cauca (ACIN), criado em 1994 junto com Movimento juvenil Álvaro Ulcué.

A partir desse programa, as mulheres indígenas Nasa (em Cauca, Colômbia) consolidaram ferramentas e formas de organização não apenas para visibilizar-se, mas, para exigir o fim da violência, principalmente a sexual, mediante a participação ativa no âmbito público. Essa dinâmica incidiu na transformação da realidade, e eviden- ciou discursos e práticas que negam o buen viver pois submetiam as mulheres mediante o medo. Assim, as lideranças femininas exigiram premissas e valores de dualidade equilibrada e complementariedade, questionando a legitimidade de algumas lideranças masculinas acusadas de violência intrafamiliar ou irresponsabilidade diante da paternidade. Deste lugar político, as mulheres indígenas Nasa reelaboraram a submissão patriarcal. Isto é, em Cauca a etnicidade constrói o conceito de gênero, tencionando e possibilitando transformações socioculturais e políticas (Botero, 2016). A experiência das indígenas Nasa - relativamente distante do Amazonas e das Ticuna - serve como referência, pois os movimentos políticos das mulheres indígenas dialogam e as experiências dos Nasa influenciam outros povos no país.

Avelina Pancho (2007), indígena e acadêmica Nasa, reivindica a centralidade das mulheres indígenas colombianas nos processos organizativos dos seus povos e enfatiza a presença ativa das indígenas em todas as ações promovidas pelo Consejo Regional Indígena del Cauca - CRIC. Mulheres compromissadas embora silenciosas, que, como portadoras da história, relembram o sofrimento e a rejeição da dominação. As mulheres indígenas não ocupam suas mãos apenas no âmbito doméstico, diante da repressão estatal se tornam colunas de defesa. O reconhecimento dessas capacidades lhes permitiu serem eleitas como governadoras, coordenadoras de programas, conselheiras ou ativistas organizadas.

No passado as mulheres indígenas na 
Colômbia não ocupavam esses cargos, apesar de que a história documentou a trajetória de cacicas poderosas como a Gaitana que, em defesa do território Nasa enfrentou a Pedro de Añasco, temido conquistador espanhol. É satisfatório o ativismo das mulheres indígenas colombianas, contudo as dificuldades persistem. Ainda não se conquistou a equidade em termos de oportunidades, tempo e espaço diante das múltiplas funções atribuídas no contexto atual. O processo organizativo indígena feminino iniciou disputando o direito de participar das reuniões, encontros, seminários e, principalmente, da tomada de decisões. Atualmente, exigem o direito da participação na política e na organização desses povos (Pancho, 2007).

Esse processo político que as mulheres indígenas protagonizam surgiu atrelado às suas condições individuais e sociais, conforme se descreve a seguir. As mulheres indígenas que lideram essas dinâmicas no Brasil lutam por construir uma experiência profissional, escolaridade, além do bilinguismo, aspectos relevantes para a compreensão da sociedade nacional e úteis para a mobilização indígena na conjuntura atual. No tocante à experiência, destaca-se sua atuação como professoras ou profissionais da área da saúde dentro das aldeias. Note-se que essas atividades produtivas e profissionais do âmbito público detonam a delimitação do mercado de trabalho a partir do sexo como critério delimitador.

O debate acadêmico é relativamente consensual no entendimento de que as mulheres pertencentes a grupos étnicos constroem feminismos ${ }^{3}$ ancorados na defesa de direitos coletivos, sem os quais não seria possível a reprodução da vida, das tradições e dos povos (Miñoso, 2014). Acadêmicas indígenas, principalmente na Guatemala e na Bolívia, introduziram a noção de "feminismo comunitário" que se revela como manifestação política feminina de denúncia das violências sofridas dentro e fora dos territórios nativos (Cabnal, 2014). Segundo Dutra e Bandeira (2016), essa proposta epistêmica marca avanços político-teóricos atrelados à realidade indígena e defronte ao feminismo eurocentrado.

Para Gargallo (2014), o feminismo é uma teorização, um ato de rebeldia ao status quo da superioridade masculina. Dita superioridade justifica a condição de exclusão dos poderes político e econômico que colocam as mulheres em funções sociais "dentro" - dentro do lar, como trabalhadora doméstica e mantenedora das redes afetivas de parentesco, e dentro da aldeia, defendendo a cultura e as tradições - as quais relegam a interação com o mundo externo. Nessa lógica, são cerceadas as possibilidades de ação feminina indígena no campo político interétnico. Esse cerceamento se impõe como um fenômeno de longa duração, a colonialidade do poder (Quijano, 2005).

Portanto, majoritariamente, as reflexões das feministas dos povos indígenas elaboram estratégias comunitárias voltadas para melhorar as condições de vida das mulheres. Contudo, essas dinâmicas não poderiam existir fora da conotação dos anseios coletivos dos seus povos. Assim, as análises das nar- 
rativas das mulheres indígenas Ticuna nas perspectivas feministas contribuem para equacioná-las como construtos que também remetem à subordinação feminina, muitas vezes naturalizada ou apagada no campo político interétnico. Conforme Piscitelli (2002), dita subordinação é socialmente construída, portanto passível de mudança. Nesse sentido, indaga-se sobre horizontes processuais de reelaboração ou reposicionamento do lugar da mulher Ticuna em décadas recentes. $\mathrm{Na}$ estrutura deste trabalho, além desta introdução, se apresenta uma breve revisão sobre a história do povo Ticuna na fronteira colombo-brasileira, a seguir são abordadas as narrativas de três mulheres lideranças Ticuna, e encerra-se com a conclusão. Apresenta-se um olhar de fora desse campo interétnico, e distanciado em muitos sentidos, principalmente pelo lugar de fala das autoras como mulheres brancas com pretensões de compreensão dos embates políticos dos povos indígenas na América Latina.

\section{OS TICUNA NA FRONTEIRA CO- LOMBO-BRASILEIRA}

O povo Ticuna habita a região geográfica do rio Amazonas/Solimões, na fronteira tríplice do Brasil, Colômbia e Peru, em uma extensão aproximada de $600 \mathrm{~km}^{2}$. São o mais numeroso povo indígena na Amazônia brasileira, abrangendo mais de 53 mil pessoas (Siasi/Sesai, 2014). Destes, 39.349 (IBGE, 2010) $^{4}$ vivem em mais de 20 Terras Indígenas, distribuídas em seis municípios da região do alto rio Solimões: Tabatinga, Benjamim Constant, São Paulo de Olivença, Amaturá, Santo Antônio do Içá e Tonantins. Na Colômbia são cerca de 8.000 indivíduos (Goulard, J. P., 2011) $)^{5}$ que habitam o departamento ${ }^{6}$ do Amazonas, nos municípios de Leticia e Puerto Nariño. A população Ticuna nos três países é de aproximadamente 70 mil indivíduos ${ }^{7}$.

Os Ticuna se autodenominam como Magüta, que quer dizer "povo pescado com vara”, o que remete a história do seu mito de criação ${ }^{8}$. Seu lugar de origem é o Igarapé Eware, no Brasil. Ali os heróis míticos Yoi e Ipi pescaram o povo Ticuna e os demais povos existentes. É o lugar onde tudo começou, em um tempo em que não existiam fronteiras nacionais. Do Eware os Ticuna se deslocaram para habitar todo esse grande território, que hoje é parte do Brasil, do Peru e da Colômbia. 


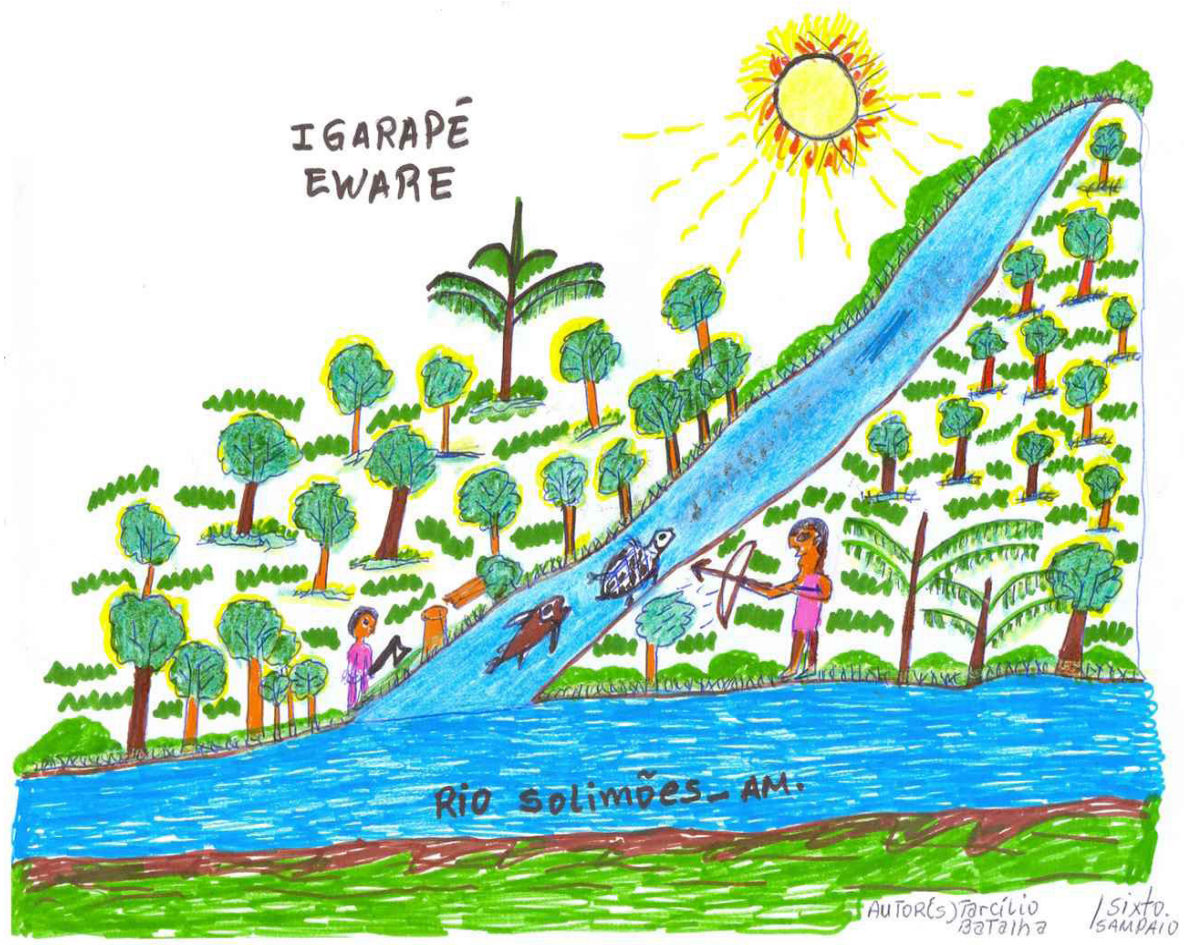

O mito de criação Ticuna: o Igarapé Eware, o lugar sagrado onde o povo Ticuna foi pescado. Ilustração de Tarcílio Batalha e Sixto Sampaio (Pinheiro, 1984) .

A região do alto rio Amazonas/alto rio Solimões foi palco de violentos processos de colonização. Julio Melatti em seu compêndio "Áreas Etnográficas" (2016) relata os movimentos colonizadores nesses quatro séculos de relações interétnicas, envolvendo desde o regime de encomiendas, a exploração da mão de obra indígena para o trabalho nas plantações, na pesca, até a exploração extrativista da borracha e o chamado regime de barracão (Oliveira Filho, 1988), situação de submissão que persistiu até a década de 1970. Nesse artigo, se problematizam alguns dos processos de transformação da organização social e política nas últimas décadas, com foco nos desafios de "ser liderança femini- na" no campo interétnico do Alto Solimões e do Alto Amazonas.

Segundo Oliveira Filho (1988), a cultura política remete a capacidade de determinados agentes sociais - instituições e organizações - produzirem uma certa ordem sobre os outros componentes da cena política, por meio da imposição de interesses, valores e padrões organizativos. No Brasil, a partir da demarcação das terras Tícuna no início dos anos 90 , houve crescimento da população indígena e uma interação cada vez maior com a sociedade dominante, sempre marcada por conflitos e relações de poder assimétricas. A demanda crescente dos Ticuna às políticas públicas de Estado, notadamente 
saúde, educação e benefícios sociais, que deveriam ser políticas diferenciadas e nem sempre o são, também é um desdobramento desse processo.

Como no Brasil, os povos indígenas da Colômbia foram vistos como empecilho e obstáculo ao desenvolvimento da nação e à criação de uma identidade nacional e, assim, tanto Estado como Igreja tiveram papel fundamental na tentativa de integração dos "silvícolas" à sociedade nacional. Antes de 1991, as constituições colombianas projetaram a ideia de uma Colômbia branca e católica. As décadas de 1960 e 1970 foram especialmente marcadas pela luta de guerrilhas, ação de paramilitares e mobilizações camponesas e indígenas em luta pela terra. A violência política elevou a incapacidade do Estado de administrar a unidade territorial. De acordo com Pereira (2011), a difícil conjuntura sociopolítica aliada à tendência de descentralização estatal (reforçada pelos ideais de democracia participativa que ganhou força no interior dos projetos neoliberais em toda a América) e a atuação dos movimentos sociais - dos movimentos indígenas e afrodescendentes em particular -, abriu espaço para a reforma constitucional colombiana de 1991. A ideia de uma nação multiétnica foi expressa na Constituição Federal de 1991 em seu artigo 7: “El estado reconoce y protege la diversidad étnica y cultural de la Nación colombiana" e também no artigo 330: "De conformidad con la Constituición y las leyes, los territorios indígenas estarán gobernados por concejos conformados y reglamentados según los usos y costumbres de sus comunidades [...]".
A constituição colombiana assegura a existência de modelos de gestão político-administrativos de base étnica - as ETIs (Entidades Territoriales Indígenas), pelas quais os resguardos passam a ter o mesmo estatuto jurídico-administrativo de departamentos, distritos e municípios (Idem., p.79). Contudo, ainda segundo Pereira (idem), toda essa dinâmica constitucional revelou conflitos e contradições internas e externas ao movimento indígena colombiano.

É nesse contexto de relações interétnicas complexas, a partir do final da década de 1990, que as mulheres Ticuna conquistam espaços de poder, alertando para mudanças que, embora necessárias, não ocorrem sem conflito. Oliveira Filho (1988), apontou os papéis políticos que emergiam da esfera pública naquele momento, relacionando-os aos que Roberto Cardoso de Oliveira (1972) havia encontrado na década de 1950-1960. Nela, jovens e mulheres não tinham lugar. Atualmente, o cenário político se complexificou e novos sujeitos atuam nas comunidades, compartilhando e disputando espaço, legitimidade e prestígio.

Do lado brasileiro são muitos novos atores, porque as comunidades são muito grandes, complexas. Professor, agente de saúde, funcionário público, funcionário da Funai, são autoridades dentro das comunidades. Diretores da Igreja, delegado da Piasol, presidente de bairro, conselheiro distrital de saúde, mas o cacique apesar de tudo, continua sendo a maior autoridade da comunidade. Conselheiros distrital de saúde, funcionário da Funai, ex-caciques que continuam atuando. Todos fazem questão de ter uma postura de lideranca. (Entrevista com Mislene 
Mendes, Benjamin Constant, em 20/09/2014).

De acordo com Mislene Mendes, mulher Ticuna e jovem liderança, atual Coordenadora Regional da Fundação Nacional do Índio (Funai) no Alto Solimões, uma das principais qualidades das lideranças deve ser a de entender como funciona o Estado. Por isso, reconhece a tendência atual das comunidades de elegerem jovens caciques, em torno de seus 30 anos, ou até mais novos. Essa é também uma tendência dos indígenas Ticuna na Colômbia. Outrossim, conforme Souza et al (2015), as lideranças que atuam no campo interétnico carregam o desafio gigante de romper com as lógicas ocidentais que idealizam a política indígena, respeitar os arranjos e as lógicas próprias, e conviver com as múltiplas dimensionalidades e temporalidades presentes no campo político indígena atual.

Nos discursos dos interlocutores entrevistados, lideranças homens e mulheres, os novos papéis, práticas e disputas que envolvem a função de liderança estão em constante ajuste face às relações recentemente estabelecidas entre os diversos povos indígenas e o Estado nacional, que exigem um ferramental político e técnico especializado para lidar com a burocracia estatal. Mais ainda, impõe visões e valores, modos de participação, metodologias e linguagens ainda em processo de negociação, apropriação, avaliação e entendimento pelas lideranças, movimentos indígenas e seus colaboradores. Contudo, essa aproximação tem consequências, entre elas, a maior influência dos Estados nacionais sobre as práticas co- tidianas dos povos indígenas.

Nesse sentido, ganha destaque a questão da formação de lideranças e o como essa temática é refletida pelas mulheres Ticuna. Como já dito, o campo político, seja no Alto Amazonas (Colômbia) ou no Alto Solimões (Brasil), recentemente começou a abrir espaço para novos atores, como os jovens e as mulheres. Nos relatos colhidos, sobressai a esperança das mulheres indígenas em agregar pensamentos mais coletivos, voltados ao bem-estar comunitário, em um cenário político interétnico que tem se pautado pelo modelo ocidental e suas lógicas individualistas e capitalistas. Esses anseios remetem ao debate proposto por Miñoso (2014) sobre a centralidade das reivindicações coletivas nos feminismos étnicos.

Entretanto, como aponta Garcés (2000), ao observar o campo político Ticuna em cada lado da fronteira Peru-Brasil-Colômbia evidencia-se a diversidade de processos históricos e socioculturais que o povo Magüta enfrentou, e continua enfrentando, pelo fato de viver em regimes políticos e contextos nacionais distintos. Também fica claro que a atual conjuntura social e política tem exigido dos povos indígenas novos modos de viver e de relacionar-se com as sociedades majoritárias. O desafio atual remete a luta pelo direito de ser indígena e superar o sofrimento como imposição sociológica do contato interétnico na fronteira (Souza et al, 2015).

Assim, às qualidades de liderança valorizadas pelos indígenas tais como prestígio, honestidade, reconhecimento comunitário, conhecimento e prática 
da cultura, abnegação e auto sacrifício pelo bem comum, foram agregadas outras, afins com as necessidades de relacionamento com as sociedades modernas ocidentais. Conhecer a legislação e os direitos indígenas, saber falar e escrever na língua nacional, ser capaz de dialogar com os poderes públicos e organismos não governamentais, saber gerir projetos e recursos de fundos públicos e privados, participar da construção, acompanhamento, monitoramento e avaliação de políticas públicas são habilidades técnicas que foram impostas aos líderes indígenas.

Diante do caráter avassalador dessa imposição estatal, os Ticuna desenvolveram estratégias diferentes para se relacionar com os respectivos Estados nacionais. Portanto, os caminhos nem sempre são os mesmos para os Ticuna brasileiros ou colombianos. Conforme Mislene Mendes explicitou em entrevista, há mais de uma década, seu pai e demais lideranças falavam da importância dos jovens e crianças escolherem formações universitárias voltadas para as necessidades do próprio povo: "Ah, a gente tem que ter nosso médico, nosso enfermeiro, nosso antropólogo, nosso engenheiro" (Benjamin Constant, 20 de setembro de 2014). Para os Ticuna no Brasil, o conhecimento técnico ocidental se colocou como instrumento chave para relacionar-se com a sociedade dominante.

Gersem Luciano (2011), liderança indígena do povo Baniwa do alto rio Negro (Brasil), doutor em antropologia pela Universidade de Brasília, corrobora com essa compreensão quando afirma que a inserção indígena no ensino oci- dental, com todas as suas idiossincrasias, é almejada pelos povos indígenas como uma estratégia para melhorar a capacidade de interlocução com o mundo dos brancos. Incursionar na escola torna-se um meio para apropriar-se das formas e práticas ocidentais de ser e estar no mundo e principalmente, dominar a palavra, a língua portuguesa. Nessa perspectiva o diploma torna-se um instrumento de luta.

Nessa lógica, quando o campus da Universidade Federal do Amazonas (UFAM) foi instalado em Benjamin Constant (Brasil), Mislene Mendes, liderança Ticuna brasileira, decidiu estudar antropologia, com a intenção de não sair da região e ser útil para o seu povo. Tal como ela, outros jovens Ticuna pareceram concordar com o fato de que o conhecimento acadêmico se tornou uma condição primordial para exercer a liderança indígena. Assim, na região do Alto Solimões, a estratégia de atuação das jovens lideranças passa pela educação escolarizada e principalmente, pelo acesso ao ensino superior, incidindo em um significativo número de estudantes Ticuna nas universidades brasileiras.

Sem deixar de considerar a nova situação que os tempos atuais trouxeram: os projetos de vida individuais direcionam os sonhos (e não apenas as demandas comunitárias e coletivas) e o desejo dos jovens Ticuna por um emprego/ salário. Contudo, vale explicitar que, no âmbito do Alto Solimões (Brasil), nesse momento não há um projeto de educação própria sendo debatido, seja no ensino formal ou não. Já no Alto Amazonas (Colômbia), há esforços volta- 
dos à construção de uma educação escolar, mas não relacionados à educação superior, como já ocorre com outros povos indígenas, em outras partes do país $^{10}$. Contudo, a carência de projetos próprios em ensino superior se coloca como importante desafio dada a sua importância no contexto de relações interétnicas atuais.

Os Ticuna colombianos também entendem a formação técnica ocidental como um requisito fundamental para interagir com os representantes estatais e negociar seus planos de vida de "gobierno a gobierno". A educação própria está prevista nos Planos de Vida das Organizações Indígenas Locais em Letícia e Puerto Narinõ. O próximo passo é a institucionalização da Escuela Democratica de Lideres - uma proposta de formação permanente para ensinar as questões da política interétnica e da política pública às e aos jovens indígenas das mais de 20 etnias que ali habitam, entre os quais os Muiname, Inga, Andoque, Yukuna, Bora, Miranha, Cambeba, Ocaina, Muri, Meneca, Uitoto, Iágua, Cocama, Kanamari, Caixana, Urarina, Jébero, Orejón, Resígaro, Chayahuíta, Nomóia e Maioruna.

Em 2014, uma vertente da formação de lideranças políticas no Alto Amazonas (Colômbia) estava vinculada ao projeto da Fundación Caminos de Identidad (Fucai) ${ }^{11}$ que, em parceria com as organizações indígenas locais constituíram a Escuela de Formación Democratica Indigena (ESFODIN). O projeto de formação política autóctone iniciado em 2007 era realizado pela Fucai, com financiamento do Ministério da Educação Nacional, e em parceria com a
Asociación de Cabildos Indígenas del Trapecio Amazónico (Acitam) e a Asociación de Cabildos Indígenas Ticunas, Cocamas y Yaguas (Aticoya). Sua meta era a formação de lideranças indígenas para atuarem com as políticas públicas, construir um projeto político indígena do Amazonas colombiano e ampliar a participação indígena nas esferas de governança local e regional, inclusive nos espaços legislativos. Esse é um objetivo partilhado pelas associações indígenas do Trapézio Amazônico Colombiano (Souza et al. 2016).

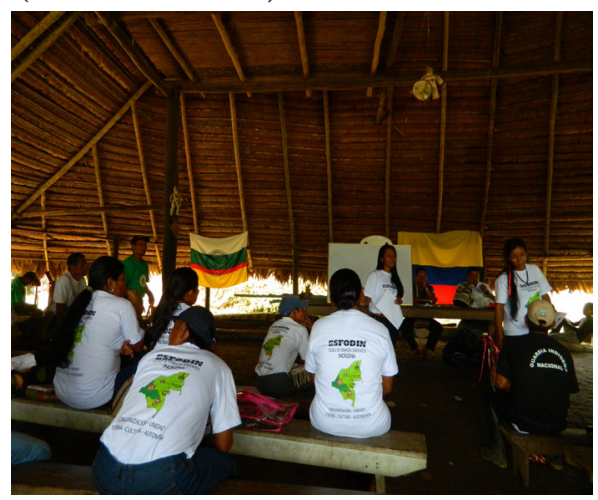

Assembleia da ESFODIN, realizada de 13 a 16/10/2014, no Resguardo Ticuna de San Martín de Amacayacu, município de Puerto Nariño (foto: Liliana de Salvo Souza).

Segundo Alis Puricha Peña, líder'Ticuna do Resguardo Aticoya ${ }^{12}$, no município de Puerto Nariño, já existem "procesos organizativos para las mujeres indígenas que terminan el grado 11 del bachillerato ${ }^{13}$. Se busca que continúen estudiando el nivel técnico" (entrevista realizada em um encontro da ESFODIN, no Resguardo de San Martín de Amacayacu, em 16 de outubro de 2014). Chama a atenção que se almeje o ensino técnico e não o universitário, como no caso brasileiro. 
Não obstante os esforços dos indígenas colombianos em institucionalizar uma política diferenciada de ingresso ao ensino superior, a experiência brasileira encontra-se melhor consolidada, apesar dos percalços ${ }^{14}$.

Este subtítulo buscou apresentar um breve panorama do povo Ticuna na fronteira colombo-brasileira na contemporaneidade, com destaque para as reformulações nas concepções de liderança indígena tradicional. Das narrativas se infere que o reconhecimento da juventude e das mulheres se impõe como desafio. No presente desse campo intersocietário, a dimensão de gênero ganha relevo. No item a seguir se enfatizam as narrativas de jovens mulheres Ticuna sobre sua incursão como lideranças na cena política, apesar da resistência cultural.

\section{MULHERES TICUNA NA LIDERANÇA}

As narrativas das indígenas Ticuna Ruth Lorenzo, Mislene Mendes e Alis Puricha Peña versam sobre suas trajetórias de vida, as quais interpelam a naturalização da subordinação feminina no campo interétnico amazônico. Suas experiências individuais remetem a transformações culturais e políticas em curso. Segundo os relatos, há aproximadamente duas décadas que as mulheres Ticuna incursionaram no campo político interétnico do Trapézio Amazônico. Esse fenômeno sociopolítico ainda não tem sido objeto de reflexão acadêmica sistemática. A esse debate pretendemos contribuir com esta análise.
Nem todas as mulheres citadas neste artigo são autoridades tradicionais Ticuna, mas todas atuam como mediadoras interculturais, dada sua expertise linguística e domínio dos códigos indígenas e das sociedades envolventes. Segundo Bartolomé (2002), essas lideranças tornam-se membros de uma crescente intelectualidade indígena cuja bagagem e trajetória podem ser contraditórias com as perspectivas dos seus povos. Esta condição não as desabilita de sua lógica própria e das tradições de sua cultura, muito embora esse empreendimento fique mais arriscado, pois o cabedal das tradições culturais é algo que se adquire pouco a pouco - e ao longo da vida. Sendo isto parte da complexidade que envolve os feminismos indígenas e as perspectivas intergeracionais.

A trajetória de Ruth Lorenzo - 46 anos, casada, diplomada ${ }^{15}$ em Direitos Humanos, em 2014 trabalhava com a temática de mulheres e jovens indígenas no Departamento de Asuntos Étnicos da Gobernación de Amazonas (Colômbia) - assinala que foi a primeira mulher indígena a tornar-se curaca no Trapézio Amazônico colombiano, em 1999. A figura do curaca remete aos "të/ $t i "$ - chefes de grupos locais - que detinham poderes mágicos e habilidades para tratar com não indígenas. $\mathrm{Na}$ relação tutelar instaurada pelo poder estatal colombiano, essa figura foi substituída pelo capitão que cumpria a função de tradutor e mensageiro, e, nessa dinâmica de falar, ler e escrever na língua nacional foram gradualmente substituindo as competências tradicionais (Oliveira Filho, 1988: 118). $\mathrm{Na}$ 
Colômbia, as figuras curaca e capitão possuem sentido histórico comum.

A institucionalização contemporânea do curaca entre os Ticuna do Trapézio Amazônico colombiano remete a representação indígena diante do poder estatal em seus diferentes níveis, municipal, departamental e nacional. Além de fazer cumprir as normas internas e definir conjuntamente os trabalhos coletivos a serem realizados nos resguardos, como representantes legais os curacas devem assumir a interlocução formal com os poderes públicos, a construção e o monitoramento de políticas públicas, e a administração de recursos públicos. A eleição para o cargo é anual, podendo ocorrer a reeleição, quando a gestão é reconhecida coletivamente. Esse processo sugere a aproximação indígena aos ideais democráticos da sociedade ocidental.

Ruth Lorenzo expôs que nasceu em uma família de curacas. Essa referência é importante, pois, no contexto da tradição Ticuna, esse cargo era herdado de pai para filho. Inicialmente, sua condição de mulher se mostrou um empecilho para ambicionar o exercício do cargo. Trata-se de um quadro cognitivo interiorizado pela própria Ruth, que lamenta ter nascido mulher.

Mi papá fue cacique o curaca de acá, mis abuelos, como que, de generación en generación, pero lamentablemente nací como mujer. La palabra mujer es muy dura, porque uno es la madre, que tiene que ver con todo (entrevista realizada no Resguardo de San Sebastián, em 05/10/2014).

A narrativa destaca a reflexividade em torno das implicações de ser mulher em condições de subordinação. Nesse quadro, se colocam as possibilidades e limites para o exercício de funções sociais, além das de natureza reprodutiva. Também evidencia a justaposição de responsabilidades dos âmbitos doméstico e público.

[...] entonces a través de mi liderazgo, empecé a los 17 años, de abí me nombraron, la comunidad, como docente, como profesora. [...] casi a mi no me gustaba ser profesora, asi de estar en aula con los niños, entonces yo ahi más bien empecé a prepararme para estudiar. Fui graduada en el 2.000 [...] yo tenía que estudiar y trabajar al mismo tiempo, y también continuar con el liderazgo [...] Me sometí a eso de los tres cargos, y más, como mamá, toca responsabilizarse de los hijos (Idem).

A nomeação como professora enquadra-se na concepção da divisão sexual do trabalho e nas tarefas femininas tradicionais. No entanto, a experiência como professora a colocou em lugar distinto ao "adentro" referido por Gargallo (2014). Nesse percurso, a formação escolar e a expertise nas funções como professora, vocal - funções de monitoramento e apoio - e tesoureira na Asociacion de Cabildos Indígenas del Trapecio Amazónico (ACITAM) constituíram-se em capital para tornar-se a primeira mulher da região a alcançar esse lugar de destaque no campo político interétnico.

$$
\begin{aligned}
& \text { [...] en } 1999 \text { fue que me eligieron como } \\
& \text { curaca [...] Porque nadie se metía [...] } \\
& \text { Uno conocía que la mayoría son muy ma- } \\
& \text { chistas [...] Pero yo me mantuve porque, } \\
& \text { al mismo tiempo, fui preparada [...] } \\
& \text { además en la Constitución está escrito } \\
& \text { que la mujer es la base fundamental [...] }
\end{aligned}
$$


Y, empecé a trabajar más duro todavia. [...] Entonces, después, me va aceptando la gente $[. .$.$] la nueva curaca, decian, ya$ ha venido trabajando como vocal, tesorera de Acitam, ahorita ella es la curaca, la primera mujer de nuestra organización, y aplauden (Idem).

Segundo relatou, tornar-se a primeira mulher curaca Ticuna constituiu uma empreitada ancorada na ancestralidade - vinha de uma família de curacas - e na visão das organizações indígenas em nível regional e nacional. A Organización de los Pueblos Indígenas de la Amazonía Colombiana (OPIAC) e a Organización Nacional Indígena de Colombia (ONIC), na época postularam o fortalecimento da liderança feminina em seu projeto institucional:

Últimamente, en Colombia, [...] esas organizaciones tienen sus representantes de mujeres. Entonces, ellas son las que coordinan con las bases, [...] con sus comunidades indígenas [...] se coordina con la coordinadora regional y es ella la que nos representa a nivel nacional. [...] Eso se hace desde 1999, me di cuenta cuando fui curaca, ya tenian esas funciones. Yo no lo sabía. Y allá fue que yo aprendí. Es por eso que la organización que yo manejo acá es de esa época. ASUMINSE se llama, Asociación de Mujeres Indígenas de San Sebastián de Los Lagos, fue fundada con 45 mujeres, con esas 45, las primeras que estuvieron acá hasta abora siguen, pero abora ha aumentado más, ya no son 45, sino 113 mijeres (Idem).

Contudo, admite que enfrentar sua condição subalterna por ser mulher foi determinante para romper com padrões de machismo internalizados entre as lideranças masculinas do movimento indígena do Trapézio Amazô- nico colombiano. Em primeiro lugar, precisou superar a intimidação pessoal diante da rejeição da sua nomeação por ser mulher. E, de outro lado, a discriminação do seu povo por ter indicado uma mulher como curaca:

\section{(...) Porque es que primero, los hombres} dijeron: "Huy, eso es terrible!" Cuando yo, por primera vez, me presenté hasta me asusté mucho, porque muchas veces ellos dijeron: "¿Cómo así, que de San Sebastián, una mujer? ¿Ya solo hay ahi maricas?" (sonrisas) iAy! ipuro gay! (...) (...) Pero, al mismo tiempo habia mucha crítica, y yo calladita, no le puse pelo a esas cosas, no. (...).

Ya después, ellos vieron que una mujer puede [...] Después, cuando yo ya me retiré, cuando cumpli los 6 años y me retiré de curaca, muchas veces decian: "usted nos hace falta, ¿por qué no vuelve?". "No, yo no quiero más, déjame trabajar, estoy estudiando otra cosa" (Idem).

Betty Alexandra Souza, liderança Ticuna, mãe de dois filhos, diplomada em Democracia, enfermeira responsável pelo Posto de Saúde do mesmo Resguardo, San Sebastián de Los Lagos, reafirma o pioneirismo do trabalho desenvolvido por Ruth Lorenzo. Esse pioneirismo enquanto liderança feminina é destacado como mobilizador da organização das mulheres Ticuna colombianas, até então incipiente.

En el pasado la organización de mujeres indigenas habia estado muy apaciguada. Ahora se ba vuelto a reactivar. Ruth que es la que lidera actualmente ha sido una de las pioneras en todo este proceso y eso ha hecho de que la mujer se vea más activa en las mingas [mutirões em português], en las asambleas, en el trabajo comunitario, en la organización en general y empecemos a tener más interés por nosotras mismas. 
Ese interés, podemos decir, que en estos momentos es lo más fuerte de la organización de las mijeres. (Entrevista realizada no Resguardo de San Sebastián, em 18/10/2014).

O desempenho de Ruth Lorenzo dinamiza a inserção de outras mulheres Ticuna no âmbito público. Essa dinâmica se traduz em transformações individuas dessas mulheres, por exemplo melhoria da autoestima. Mas também em transformações coletivas; o despertar do interesse pelas questões relativas ao universo feminino é colocado como capital político e sociocultural fundamental no processo de organização das mulheres Ticuna.

A trajetória de Mislene Mendes, liderança feminina Ticuna do Alto Solimões (Brasil) tem alguns espelhamentos com o percurso de Ruth Lorenzo em Leticia (Colômbia). Casou jovem, seu marido não é indígena, tem três filhas. É filha de Paulo Mendes, um dos líderes pioneiros do movimento político indígena do Alto Solimões, e sua mãe é uma indígena Cocama. Ainda criança, junto com a mãe e os irmãos, mudou-se da aldeia Vendaval para Benjamin Constant com o objetivo de estudar. Fez o primário, o ensino fundamental, o ensino médio e a universidade na "escola do branco". Relatou que apesar da presença de indígenas em sala de aula, muitos não assumiam a identidade indígena e o preconceito escolar e institucional era forte.

Com 19 anos foi aprovada no vestibular para cursar Antropologia na Universidade Federal do Amazonas, motivada pelos anseios do pai que "queria que participasse das assembleias e das festas do movimento indígena" (Benjamin Constant, 20 de setembro de 2014). Em julho de 2014 se tornou a primeira mulher Ticuna indicada para ocupar o posto de coordenadora da Regional da Funai no Alto Solimões. Funcionária pública concursada revela que quando da sua nomeação, ao assumir o cargo de coordenadora, teve de contestar as críticas e enfrentar o desencorajamento dos atores na cena política local ${ }^{16}$ : - "Você é nova, você é mulher, até hoje só teve coordenador homem e de mais idade, com experiência"; - "Ah! é mulher, quando ela tiver um problema ela vai chorar"(Idem). Críticas que expressam as ideias fundantes do patriarcalismo que relega às mulheres e à juventude um lugar de subalternidade.

Portanto, o posicionamento de alguns $^{17}$ atores da cena política interétnica é claramente pautado em lógicas machistas e patriarcais que se nutrem da ideia de superioridade masculina. Segundo afirmou "Ticuna é super machista, falo isso dentro de casa, meu pai é machista". Apesar desse contexto, afirma que "independentemente de qualquer conflito e acusação, respeito todos os velhos". Esse depoimento remete a centralidade da liderança tradicional na redefinição da ação política das lideranças indígenas femininas. Isto é, os referentes culturais e da tradição condicionam a agência das mulheres Ticuna, assim como as pautas que elas propõem surgem, também, dos anseios coletivos do seu povo.

Sua narrativa destaca que a incursão feminina Ticuna nos espaços da cena política interétnica ocorreu apesar da resistência masculina "[...] as mulheres 
são lideranças, querendo os homens ou não". Reconhece ser "um evento novo, mas existem mulheres no Alto Solimões que estão se levantando, buscando espaço [...]”. Segundo ela, as mulheres Ticuna na liderança "exercem papéis superimportantes" (Idem). Essa importância, como se retoma adiante, é dada pela ênfase na busca por uma participação mais abrangente na liderança indígena, que possibilite a inserção dos jovens e das mulheres. Essa centralidade da presença masculina e dos mais velhos nos espaços de poder têm sido questionada nos debates acadêmicos que defendem a necessidade de subverter dito padrão, de modo a abrir a participação política mediante considerações de gênero. Nessa trilha, a indígena colombiana Avelina Pancho (2007) argumenta que a categoria gênero poderia constituir-se em eixo transversal das pedagogias políticas desses povos.

Para Alis Puricha Peña, mulher Ticuna colombiana, neta de lideranças e vice-presidente da organização Asociación de Cabildos Indigenas Ticunas, Cocamas y Yaguas - Aticoya, a participação de mulheres indígenas no campo interétnico implica em atributos de gênero. Explicou que antes de tornar-se líder indígena sua vida era demarcada pelo âmbito doméstico "la casa, la chagra, esposo y hijos”. Somente após a separação do marido se iniciou na cena pública e política do Trapézio Amazônico. Seu tio, que era líder da comunidade São Francisco, no Resguardo de Aticoya, foi quem a convidou para participar de reuniões (entrevista realizada no Resguardo de San Martín de Amacayacu, em 16 de outubro de 2014). Note-se que o deslocamento dessa liderança do âmbito doméstico para o público foi mediado por um homem reconhecido em ambas as esferas.

Alis ressaltou que foi o tio quem a postulou como liderança. Segundo ela, esse convite masculino abriu as portas para a sua candidatura e eleição como vice-presidente da organização Aticoya. Teria dito: "sobrina ¿qué haces acá? [...] usted tiene que ser lider, usted nos va a representar, usted será nuestra vice-presidente". Explicitou que duas razões a motivaram a participar do movimento indígena. Em primeiro lugar, a luta por uma participação equitativa das lideranças da organização indígena pluriétnica. Em segundo lugar, a necessidade de propor uma administração mais transparente dos recursos financeiros (entrevista realizada no Resguardo de San Martín de Amacayacu, 16 de outubro de 2014).

Conforme afirmou, a busca por uma participação igualitária é uma qualidade da liderança feminina:

Pero, lo que queremos ahorita es la administración de mujeres [...] Entonces, eso es lo que hay que mejorar. Esas fueron las experiencias que he vivido hasta ahora. Y por el momento, hemos sido dos mujeres en nuestra organización, basta llegar a ser, a ocupar el segundo lugar de la dirección, la vicepresidencia [...] mirando el grupo de compañeras vamos a ver quién va a medirse a la presidencia [de Aticoya]. Porque el egoísmo como organizaciones o autoridades es que no le dan el espacio a los vice, a los segundos, sea vice-curaca o vice presidente [...]. Esos son los errores que se cometen, porque lo ideal no es eso, porque el liderazgo es de todos, equilibrado (Idem). 
O pensamento dessa líder Ticuna dialoga intimamente com Gargallo (2014) que colocou o feminismo como um ato de rebeldia ao status quo da superioridade masculina que fomenta a exclusão das mulheres do poder político e econômico. A participação feminina indígena exige também que os estados nacionais ampliem o foco de articulação e diálogo com esses povos, até agora centralizado nos homens indígenas, nas figuras dos tuxauas e caciques. Os Estados nacionais diuturnamente institucionalizam o machismo nas já conturbadas relações políticas com os indígenas. Corroborando com esse posicionamento, Rita Segato (2003), afirma que as indígenas atribuem a tímida participação feminina no campo político interétnico a um conjunto de restrições advindas da resistência das lideranças masculinas dos seus povos e, inclusive, do Estado brasileiro.

A dinâmica liderada pelas mulheres indígenas em Aticoya, enunciada como uma 'administração de mulheres', indica um exercício político que busca abrir novos espaços em cenários masculinizados e ocupados tradicionalmente pelos homens mais velhos Diante dessa modalidade de administração machista e patriarcal, as mulheres Ticuna se revelam politicamente denunciando, como advertiu Cabnal (2014), que os povos indígenas sofrem violências dentro e fora dos seus territórios. Segundo Alis Puricha Peña, as mulheres Ticuna de Aticoya investem na redefinição do seu lugar no campo político interétnico:

Porque eso es lo que han mirado nuestros compañeros hombres, se han dejado llevar por unas cosas negativas, $[\ldots]$ quiero que el proyecto indigena siga adelante, luchar para marcar la diferencia [...] somos nosotras, las mujeres, las que podemos administrar mejor nuestros recursos y guiar bien nuestra organización. En diferentes campos, ya podemos hacer mucho mejor a comparación de los hombres. Entonces eso es la diferencia que queremos hacer, por eso hay muchas mujeres en estos momentos que queremos ocupar esos puestos, o sea, es como una competencia que nos estamos poniendo. Si nosotras, las mujeres indígenas, podemos. Pero aqui es un reto de hacerlo mejor. Si llegamos, pues hacerlo mejor (Idem).

Esse depoimento reforça o argumento de Piscitelli (2002) que alertou que a subordinação feminina é uma condição sociopolítica passível de ser mudada por configurar-se como uma estrutura cognitiva socialmente construída. Nesse sentido, é pertinente analisar os horizontes processuais de reelaboração ou reposicionamento do lugar da mulher a partir dos depoimentos dos homens Ticuna no tocante a esse processo.

Sandro Flores, jovem liderança Ticuna do Alto Solimões, relembra que, há 20 ou 30 anos, as mulheres não tinham voz nas reuniões do movimento político indígena. Hoje, estão ganhando espaço dentro do povo Ticuna, com muito custo. Afirmou que "muitas delas são candidatas a cacique, mas não ganham porque ainda tem um certo preconceito" (entrevistado em 23 de outubro de 2014, em Tabatinga). Duas décadas se passaram desde a primeira incursão das mulheres Ticuna na cena política amazônica, e esse indicativo temporal denota que, para quebrar as barreiras 
que impedem a ampla participação feminina, requerem-se investimentos de longa duração.

Outro entrevistado relatou que uma mulher havia sido vice-cacique em Umariaçu I (Brasil), e outra era cacique em uma pequena comunidade em Belém do Solimões, em 2014. Esses relatos confirmam a ainda tímida participação das mulheres Ticuna como caciques no Alto Solimões. Contudo, indicam também mudanças nos critérios para ocupar cargos de liderança indígena. Segundo José Soria, do povo Yagua (Colômbia), assessor da ACITAM, o movimento indígena atravessa importantes transformações que configuram um momento interessante da luta política e do poder tradicional.

[...] nem jovens nem mulheres eram atores políticos. Hoje já é diferente. Muitos estão pensando na política, em ser atores na política [...]. Tem uma mudança no tema do poder tradicional. De primeiro não era possivel a mulher chegar a ter o poder tradicional, a ser curaca, a ser governadora. [Hoje] já tem uma concepção diferente do tema da participação [...].

Até agora [o movimento indígena] comesa a entender que a luta dos atores sociais tem que ser de maneira conjunta, participativa, homem e mulher, senão a balança não se pode equilibrar. Acho que isso é parte da luta também. Reconbecimento do papel da mulber dentro da luta social (entrevista realizada em Letícia, em 26/09/2014).

Os anseios dos jovens e mulheres por participarem na política impelem a transformação do poder tradicional. As mulheres Ticuna tornando-se caciques, curacas e governadoras configura-se como um fenômeno de reela- boração da compreensão em torno da participação política. De outro lado, o reconhecimento do lugar da mulher é ponderado a partir da metáfora da balança, para legitimar uma proposta de equilíbrio em prol da luta indígena. Contudo, na própria reflexão desse líder indígena, dito equilíbrio revela-se desafiador.

No seguinte trecho ponderam-se aspectos que são centrais para equacionar o caráter conflitivo da inserção feminina Ticuna no campo político interétnico. Em primeiro lugar, o apelo pela diferenciação de papeis remete a divisão internacional e social do trabalho ancorado em estruturas sexistas e privilégios masculinos, às custas da subordinação feminina.

[...] sempre pensei que a mulher tem esse lugar. Mas só que tem que diferenciar os papéis, não? [...]. Quando eu falo esse tema de gênero na luta indígena deve estar em igualdade de condições, deve ser parte, mas as mulheres devem saber entender muito bem a luta dos povos indigenas. Porque têm mulheres que tratam de partir o movimento indígena. Que estão pensando o tema da liberação, o conceito da liberaşão feminista. Da luta das mulheres da Europa, europeias, que passa por ai, o tema da liberação, essas coisas. A luta das mulheres indígenas deve ser parte da luta, para fortalecer o movimento, mas não para separar, não para quebrar o movimento indígena. E ai onde nós temos grandes diferenças com algumas liderancas mulheres, que querem tomar partido diferente (Idem).

De outro lado, a ênfase em que as mulheres indígenas precisam "saber entender muito bem a luta dos povos indígenas" traz à tona a ideia errônea de 
que até então elas teriam ficado alheias às reivindicações históricas. Essa argumentação não reconhece a centralidade das mulheres indígenas na manutenção política do processo organizativo indígena, embora demarcada ao âmbito doméstico. Isto é, na reprodução política e cultural dos povos, as mulheres além do cuidado físico e material fornecem o ensino de normas, valores e crenças $^{18}$. Por isso, a compreensão de que a incursão das mulheres indígenas na política desdobra-se em múltiplas exigências domésticas e públicas. Elas trabalham pela valorização da cultura mediante mingas e ajuris, trabalhos comunitários que fortalecem os vínculos internos entre os Ticuna. Também preservam as funções tradicionais das mulheres indígenas como parteiras, COnhecedoras das medicinas, cantoras e educadoras.

Diante do questionamento sobre como as lideranças femininas se formaram, não apenas do ponto de vista técnico ou acadêmico, mas também social e culturalmente, as trajetórias das mulheres indígenas reconhecem a herança da luta política de seus pais e familiares para fazer valer seus direitos à terra, à vida e à cultura própria. Afinal, trata-se de processos que estão interconectados: a construção indígena da "liderança política" e a formação política de suas lideranças. Em entrevista, Alis Purecha Peña afirmou que

Gracias a esos conocimientos de mis abuelos viene como la experiencia como líder. Mis abuelos eran lideres. Una herencia que uno les deja, asumir el liderazgo. Uno nace para ser lider [...] Me gusta entonces [...] Me gustaba mucho. Dios mi regaló ese don, ese ánimo de luchar [...] (Resguardo de San Martín de Amacayacu, 16 de outubro de 2014).

$\mathrm{Na}$ narrativa do assessor indígena José Soria aparece o tensionamento entre os diversos feminismos. Ele aponta a importância de um feminismo não eurocentrado, não urbano, e mais ligado à vida. Ao citar as tensões entre as pautas dos povos indígenas e as pautas feministas "brancas" e eurocêntricas se abre o debate para a crítica enfrentada pelos feminismos que surgem fora dos países centrais. Nessa ordem, Miñoso (2014) afirma que os feminismos das mulheres pertencentes a grupos étnicos se constroem fundamentados na defesa de direitos coletivos, os quais garantem a reprodução da vida, das tradições e dos povos como um todo.

Nesse sentido, a narrativa de Alis Puricha Peña, líder Ticuna colombiana reverbera a utopia de uma pauta coletiva enquanto povo Ticuna, pela defesa de direitos coletivos além das fronteiras nacionais dos três países - Brasil, Colômbia e Peru. Importante frisar que, embora não conheça os Ticuna dos outros países, declara que se fosse eleita presidenta da Aticoya, investiria para fazer intercâmbios em prol da união desse povo indígena e do conhecimento sobre as formas organizativas das mulheres.

Allá hay Ticunas brasileras, acá hay Ticunas colombianas y peruanas. Si nos queremos como indígenas, vamos a ver lo que ustedes nos pueden dar y lo que nosotras les podemos dar a ustedes. Son cosas para que finalmente o mundo indigena se una, porque somos uno solo pueblo. [...] como uno camino fuerte, porque tenemos 
que unirnos (Resguardo de San Martín de Amacayacu, 16 de outubro de 2014).

Os anseios dessa liderança feminina Ticuna remetem à análise proposta por Souza et al (2016) no tocante a importância de voltar-se para as raízes étnicas no enfrentamento dos embates que ameaçam reconfigurar a sua etnicidade. De fato, os arranjos políticos e técnicos atuais envolvem formas de gestão que exigem maior profissionalização dos Ticuna. Visando responder às exigências burocráticas, muito do que é próprio está sendo deixado de lado. $\mathrm{O}$ depoimento acima remete para um movimento no sentido inverso - conferir centralidade ao que lhes é próprio e valorizar o lugar da mulher indígena na dinâmica da manutenção das tradições, da cultura e do bem-viver.

\section{CONCLUSÃO}

No momento, na região da pesquisa, verifica-se um campo político interétnico em efervescência. Os desafios políticos contemporâneos interpelam o poder político tradicional e as mudanças em curso são potenciadas pelas novas exigências nos âmbitos institucionais. Nessa direção, as narrativas de mulheres e homens Ticuna, e das demais lideranças entrevistadas, indicaram que a ação política indígena feminina no campo interétnico na Colômbia e no Brasil alcançou avanços importantes e enfrenta desafios significativos.

$\mathrm{Na}$ análise das lideranças entrevistadas, a luta etnopolítica atual visa consumar os direitos indígenas garantidos nas Constituições latino-americanas. A formação política e técnica das lideranças indígenas é, portanto, vista como uma estratégia fundamental para garantir a efetivação dos direitos indígenas e a construção de uma política indigenista adequada às necessidades e demandas atuais dos povos indígenas. Para tanto, as mulheres lideranças Ticuna têm encarado o machismo intrincado no âmbito político. A formação acadêmica e a trajetória profissional nos moldes ocidentais constituem diferenciais para legitimar a sua inserção na esfera pública, além de qualificar seu lugar de chefia em organizações privadas ou nos respectivos governos nacionais. Ditos diferencias enquadram-se nas exigências contemporâneas que os Estados nacionais impõem aos povos indígenas.

Assim, partir da década de 2000 tanto no Brasil como na Colômbia ocorre uma tendência ao fortalecimento social feminino no âmbito das políticas públicas voltadas aos povos indígenas nas áreas de educação, saúde, segurança alimentar, benefícios sociais, moradia e 'políticas femininas' propriamente ditas. A ênfase nas políticas básicas sustenta-se na tradicional divisão social do trabalho, onde os cuidados com a família permanecem sendo atribuídos prioritariamente às mulheres. Talvez por isso as indígenas estejam sempre atentas e receptivas àquelas iniciativas governamentais que apoiam o desenvolvimento social, econômico e cultural de suas famílias e povos.

A organicidade da formação de lideranças implica em reconhecer que a transmissão desse saber no mundo contem- 
porâneo está vinculada não apenas aos processos de formação técnica, escolarizada e burocratizada. Os conhecimentos ancestrais, enraizados nas práticas da cultura, nas festas da Moça Nova, en las curaciones e bendiciones, nas assembleias e lutas políticas contribuem com conteúdo étnico insubstituível. Dentre os caminhos possíveis em meio aos novos processos políticos interétnicos, as lideranças requerem visões capazes de transitar entre os dois mundos e, ao mesmo tempo, manter a qualidade de uma ação política em seu sentido mais amplo, mais valioso - da distribuição do poder, da capacidade de manter a discussão interna, de fortalecer as redes de alianças e de valorizar o coletivo (Enric Cassú Camps, entrevista realizada em 8/09/2014 na Universidade Nacional de Colômbia, sede Leticia).

No que concerne as lideranças femininas, as trajetórias analisadas indicam ricos processos de mudança em curso. Por mais que se tenha avançado, a colonialidade e o patriarcado adjacente permanecem vigentes nas estruturas dos Estados nacionais, da sociedade e nos povos indígenas. Incidir nessa transformação paradigmática parece ser o desafio não apenas para as mulheres lideranças Ticuna, mas do movimento etnopolítico como um todo. É uma longa caminhada. Ainda há muito a fazer, mas estão no rumo.

\section{NOTAS}

${ }^{1}$ As interlocutoras permitiram sua identificação, por considerarem que a invisibilidade dos sujeitos femininos precisa ser rompida.
${ }^{2}$ A versão definitiva desse artigo foi publicada em 2006 (CARDOSO DE OLIVEIRA, Roberto. Caminhos da identidade: Ensaios sobre etnicidade e multiculturalismo. São Paulo: Editora da UNESP; Brasília: Paralelo 15, 2006).

${ }^{3}$ Em plural, para significar "a passagem do pensamento feminista "clássico", centrado nos "estudos da mulher", para estudos ancorados na pluralidade, na multiplicidade das construções de feminino e de masculino. Abre-se a possibilidade de desconstrução de um modelo universal único e androcêntrico, apontando-se para as diversidades não apenas entre os gêneros, mas também entre as próprias mulheres, e entre os homens, com referência nas observações das distinções entre as culturas, no que diz respeito aos modelos de homens e de mulheres (Bandeira \& Siqueira, 1997, p. 276-277).

4 ftp://ftp.ibge.gov.br/Censos/Censo Demografico 2010/Caracteristicas Gerais dos Indigenas/pdf/Publicacao completa.pdf . Acesso em 15/04/2015.

${ }^{5}$ Os dados demograficos utilizados estão publicados em http://pib.socioambiental.org/pt/povo/ticuna/1342. Acesso: 02/01/2017.

${ }^{6}$ O Departamento é "uma unidade político-administrativa colombiana, que para alguns efeitos poderia se assemelhar ao Estado no Brasil. Departamentos e municípios são as principais unidades da divisão política da Colômbia” (RUANO, 2013:23).

${ }^{7}$ No Peru são cerca de 6.982 (INEI, 2007).

${ }^{8} \mathrm{O}$ mito de criação Ticuna é contado por Oliveira Filho (1988:90-105), a partir da narrativa do Ticuna João Laurentino, morador do igarapé São Jerônimo, que resultou na publicação Torü Dü̈ügü (1983).

9 In http://www.taquiprati.com.br/ cronica/1134-morro-por-ela-esta-terra-seguido-de-version-en-espa, acessado em 
06/01/2017.

${ }^{10}$ Por exemplo, as mulheres indígenas Nasa lideram a Universidad Autónoma Indígena e Intercultural (UAIIN) e o programa de educação bilíngue e intercultural no âmbito da proposta programática do CRIC, em curso desde 1978. Essa iniciativa busca redimensionar a identidade indígena e o resgate das línguas originárias. A UAIIN dinamiza processos pedagógicos e de pesquisa desde as cosmovisões indígenas e saberes ancestrais. Nessa perspectiva, gênero e família constituem o eixo transversal da pedagogia e pesquisa (Pancho, 2007).

${ }^{11}$ Fundada em 1991, a Fucai é uma organização não-governamental que trabalha com comunidades locais nos temas de família, infância e juventude, formação democrática e organização comunitária, projetos educativos comunitários e formação de professores indígenas. Em 2014, atuava em 18 departamentos da Colômbia, em 100 municípios e com 35 povos indígenas.

${ }^{12}$ Os Resguardos indígenas constituem uma instituição legal e sociopolítica de caráter especial, e de origem colonial, conformados por uma comunidade ou uma parcialidade indígena, que tem o título de propriedade comunitária de seu território e, se rege por uma jurisdição indígena própria, de acordo com seus usos e costumes. Essa situação foi ratificada pela Constituição de 1991, quando os povos indígenas da Colômbia tiveram reconhecidos sua diversidade étnica, sua autodeterminação enquanto povos distintos, a educação bilíngue, o desenvolvimento cultural próprio, o direito à representação no Senado e a exercer funções jurisdicionais no seu âmbito territorial e em conformidade com suas próprias normas e procedimentos, à gestão autônoma de seus territórios, à governar-se com suas próprias autoridades, à administrar recursos públicos e participar da economia nacional (Garcés, 2000:204, tradução livre), o que acarretou outros desafios organizacionais aos movimentos indígenas no país.

${ }^{13}$ Equivalente ao ensino médio no Brasil.

${ }^{14}$ Sobre a inserção dos indígenas nas universidades brasileiras ver Coelho (2006), Paulino (2008), Luciano (2009) e Paz (2013).

${ }^{15}$ Creditação escolar obtida mediante realização de curso de ensino formal com duração entre 80 a 120 horas aula, que objetiva o aprofundamento em uma área especifica do conhecimento.

16 Até então, esse cargo era preenchido por indicação das comunidades a partir de decisões tomadas em assembleias. Neste caso, a nomeação foi realizada pela presidência da Funai, em Brasília, argumentando competência técnica. A resistência a essa nomeação se explicaria nesse contexto de entraves diante da sobreposição de interesses técnicos sobre a política interétnica no Alto Solimões.

${ }^{17}$ Esse termo busca denotar a necessidade de cuidado para não generalizar dito posicionamento a todos os homens indígenas. Nesse sentido, cabe delimitar essa assertiva como uma construção narrativa que dialoga com os sentidos conferidos pelas mulheres Ticuna e pelas feministas citadas, em torno da categoria de superioridade masculina. Conforme dito na introdução, este trabalho não pretende dar conta da diversidade de perspectivas ou conceitualizações de gênero e socialidades indígenas, apenas provocar um debate importante e necessário a partir de dados coletados em campo.

${ }^{18}$ Agradecemos a indicação do parecerista do artigo de Cristiane Lasmar sobre a literatura etnológica dos anos de 1970 e 1980, publicado na Revista Estudos Feministas, em 1999, no Dossiê organizado por Bruna Franchetto. Esse trabalho evidenciou que a literatura também reproduziu a oposição 
entre o masculino - cultura/poder/público versus o feminino - natureza/doméstico.

\section{REFERÊNCIAS}

BARTH, Fredrik. 2000. Metodologias comparativas na análise dos dados antropológicos. In: LASK, Tomke (org.). O guru, o iniciador e outras variações antropológicas. Rio de Janeiro: Contra Capa.

BANDEIRA, L \& SIQUEIRA, D. 1997:263-284. A perspectiva feminista no pensamento moderno e contemporâneo. Sociedade e Estado, v.12, n.2.

BARTOLOMÉ, M. A. 2002. Movimientos Indios en América Latina: los nuevos procesos de construcción nacionalitária. Série Antropologia, Departamento de Antropologia, Universidade de Brasília.

BÓRQUEZ, R. 2011:59-84. Mujeres indígenas, campesinas y su organización por el acceso a la tierra. In: ANDERSON, Jeanine et al. Mujer rural. Cambios e persistencias en América Latina. Lima: CEPES.

BOTERO, W. 2016:138. Mulheres indígenas da 'Çxhab Wala Kiwe': relações étnico-racial, gênero e sexualidade nos Andes colombianos. Dissertação de mestrado em Antropologia social na Universidade de São Paulo. São Paulo.

CASTILLO, R. 2008:514. Etnografías e historias de resistencia. mujeres indígenas, procesos organizativos y nuevas identidades políticas. México: Centro de Investigaciones y Estudios Superiores en Antropología Social.

CONSTITUICIÓN Política de Colombia. 2015. Disponível em: http://www.corteconstitucional.gov.co/inicio/Constitucion $\% 20$ politica $\% 20 \mathrm{de} \% 20$ Colombia $\% 20$ -\%202015.pdf , acessada em 09/01/2017.

DUTRA, D. \& BANDEIRA, L. M. 2015:115. Estudos de Gênero na América Latina: dinâmicas epistêmicas e emancipações plurais. Revista de Estudos e Pesquisas sobre as Américas, Volume 9, número 2.

CABNAL, L. 2010:11-25. Acercamiento a la construcción de la propuesta de pensamiento epistémico de las mujeres indígenas feministas comunitarias de Abya Yala. In: Feminismos diversos: el feminismo comunitario. Asociación para la cooperación con el Sur, ACSUR, Las Segovias.

CARDOSO DE OLIVEIRA, R. 1972. O indio e o mundo dos brancos. São Paulo, Livraria Pioneira Editora.

2000. Os (des)caminhos da identidade. Revista Brasileira de Ciências Sociais, Vol. 15, nº 42.

2006. Os (des)caminhos da identidade. In Caminhos da identidade: Ensaios sobre etnicidade e multiculturalismo. São Paulo: Editora da UNESP; Brasília: Paralelo 15.

COELHO, E. 2006:1-12. Ações afirmativas e povos indígenas: o princípio da diversidade em questão. Políticas Públicas. Maranhão, v.10, n.2.

GARCÉS, C. L. L. 2000. Ticunas brasileiros, colombianos y peruanos: etnicidad y nacionalidad en la región de fronteras del Alto Amazonas/Solimões. Tese, CEPPAC, UnB, Brasília, DF.

GARGALLO, F. 2014:371-381. Los feminismos de las mujeres indígenas: acciones autónomas y desafío epistémico. In: ESPINOSA MIÑOSO, Yuderkys; GÓMEZ CORREAL, Diana; OCHOA MUÑOZ, Karina (Edit.). Tejiendo de otro modo: Feminismo, epistemología y apuestas descoloniales en Abya Yala. Popayán: Editorial Universidad del Cauca.

GRUBITS, S. et al. 2005:363-372. Mulheres indígenas: poder e tradição. Psicol. estud., Maringá , v. 10, n. 3, Dec.

LAVRIN, As. 1985:384. Las mujeres lati- 
noamericanas: perspectivas históricas. México: Fondo de Cultura Económica.

LASMAR, C. 1999. Mulheres Indígenas: representações. Dossiê Mulheres Indígenas, Revista Estudos Feministas. V. 7, n. 1 e 2 .

LUCIANO, G. J. S. 2011. Educação para Manejo e Domesticação do Mundo: entre a escola ideal e a escola real. Os dilemas da educação escolar indígena no Alto Rio Negro. Tese, DAN/Universidade de Brasília, Brasília.

2009:187-202. Indígenas no Ensino Superior: Novo Desafio para as Organizações Indígenas e Indigenistas no Brasil. In: Maria Inês Smiljanc; José Pimenta; Stephen Grant Baines. (Org.). Faces da Indianidade. 1ed. Curitiba: Nexo Design, v1.

MATAREZIO F. E. T. 2014. Do corpo ao cosmos - condensações rituais dos Ticuna. Periferia, v. s.n., n. 19 (1), Juny, Barcelona, Espanha.

MELATTI, J. C. Áreas Etnográficas da América Indígena/Alto Amazonas. Disponível em: http://www.juliomelatti.pro. br/areas/f2altama.pdf, acessado em 30 de dezembro de 2016.

MIÑOSO, Y. et al. 2014:480. Tejiendo de otro modo. Feminismo, epistemología y apuestas descoloniales en Abya Yala. Popayán: UC.

OLIVEIRA F. J. P. 1977. As facções e a ordem política em uma reserva Ticuna. Dissertação, Departamento de Antropologia, Universidade de Brasília, Brasília-DF. . 1988. "O Nosso Governo”: Os Ticuna e o Regime Tutelar. São Paulo: Marco Zero; Brasília: MCT/CNPq.

PANCHO, A. 2007:53-64. Participación de las mujeres nasa en los procesos de autonomía territorial y educación propia en el Cauca, Colombia. In: DONATO et al (eds.). Mujeres indígenas, territorialidad y biodiversidad en el contexto latinoamericano. Bogotá: Universidad Nacional de Colombia/Fundación Natura de Colombia/Unión Mundial para laNaturaleza/ UNODC/Oficina de las Naciones Unidas contra la Droga y el Delito.

PAULINO, M. 2008. Povos Indígenas e Ações Afirmativas: o Caso do Paraná. Dissertação (Mestrado em Educação). Universidade Federal do Rio de Janeiro, Faculdade de Educação, Rio de Janeiro.

PAZ, A. A. M. Á. 2013. Indianizar para Descolonizar a Universidade: Itinerâncias Políticas, éticas e Epistemológicas com os Estudantes Indígenas da Universidade de Brasília. (Tese de Doutorado em Educação). Universidade de Brasília.

PEREIRA, E. 2011:69-98. Palavra de Coca e de Tabaco como "conhecimento tradicional”. Revista MANA 17(78).

PINHEIRO, P. I. 1984. (Ngematücü). Tchorü duй ü güca tchanũ / Minha luta pelo men povo. Museu Nacional/Universidade Federal do Rio de Janeiro, Rio de Janeiro, RJ.

PISCITELLI, A. 2002:7-42. Re-criando a (categoria) Mulher? In: Algranti, Leila Mezan. (Org.). A prática feminista e o conceito de gênero. Campinas: IFCH/UNICAMP, v. 48. QUIJANO, A. 2005:201-246. Colonialidad del poder, eurocentrismo y América Latina. In: La colonialidad del saber: eurocentrismo y ciencias sociales. Perspectivas latinoamericanas. / LANDER, Edgardo (org.). Buenos Aires: CLACSO.

RESENDE, V. M. \& RAMALHO, V. 2009:25-54. Análise de Discurso Crítica. São Paulo: Contexto, 2006/1ª reimpressão. RUANO IBARRA, E. del S. 2013. "Minga" e AIR em perspectiva comparada. Forma e significado nos protestos indígenas na Colômbia e no Brasil. Tese, CEPPAC, Universidade de Brasília, Brasília-DF.

SACCHI, Â. 2003:95-110. Mulheres indí- 
genas e participação política: a discussão de gênero nas organizações de mulheres indígenas. Revista Anthropológicas, v. 14, n. 1 e 2 .

SEGATO, R. L. 2003:1-2003. Uma agenda de ações afirmativas para as mulheres indígenas do Brasil. Série Antropologia (Brasília), Brasília, v. 326.

SILVA, C. T. \& BAINES, S. G. 2009. Antropologia nas Fronteiras: contribuições teóricas e etnográficas para as Ciências Sociais nas Américas. In Américas Compartilhadas. FERNANDES, Ana Maria; RANINCHESKI, Sonia (orgs.). São Paulo: Francis. SILVA, C. T. 2010. Povos Indígenas entre Estados Nacionais: Identidades, Etnicidades e Nacionalidades em Perspectiva Comparada. Trabalho apresentado na $27^{\mathrm{a}}$. Reunião Brasileira de Antropologia, Belém-Pará, Brasil.

SOUZA, L. V. S. 2015. O Entrelaçamento das Identidades Étnicas e Nacionais: Reflexões sobre o Campo Político e a Formação de Lideranças Ticuna na Fronteira do Brasil e da Colômbia. Dissertação de Mestrado, CEPPAC, UnB, Brasília-DF.

SOUZA, L. et al. 2016:195-210. Repensando a "liderança" no Alto Solimões: Metamorfoses da etnopolítica Ticuna na Amazônia brasileira e colombiana. In: IGREJA, Rebecca e NOVION, Jacques. Política em movimento: a construção da política na América Latina e Caribe. Curitiba: CRV.

ULLOA, A. 2007:17-34. Mujeres indígenas: dilemas de género y etnicidad en los escenarios latinoamericanos. In: DONATO et al (eds.). Mujeres indígenas, territorialidad y biodiversidad en el contexto latinoamericano. Bogotá: Universidad Nacional de Colombia/Fundación Natura de Colombia/Unión Mundial para laNaturaleza/UNODC/Oficina de las Naciones Unidas contra la Droga y el Delito.
Recebido entre 24 a 27/02/17

Aprovado em 21/03/17 